\title{
Erratum: Lewicka et al. Sources and Markets of Limestone Flour in Poland. Resources 2020, 9, 118
}

\author{
Ewa Lewicka *(D), Jarosław Szlugaj (D), Anna Burkowicz (D) and Krzysztof Galos \\ Mineral and Energy Economy Research Institute, Polish Academy of Sciences, J. Wybickiego 7A, \\ 31-261 Kraków, Poland; szlugaj@min-pan.krakow.pl (J.S.); burkowicz@min-pan.krakow.pl (A.B.); \\ krzysztof.galos@min-pan.krakow.pl (K.G.) \\ * Correspondence: lewicka@min-pan.krakow.pl
}

Citation: Lewicka, E.; Szlugaj, J.; Burkowicz, A.; Galos, K. Erratum: Lewicka et al. Sources and Markets of Limestone Flour in Poland. Resources 2020, 9, 118. Resources 2021, 10, 112. https://doi.org/10.3390/resources 10110112

Received: 15 October 2021

Accepted: 22 October 2021

Published: 3 November 2021

Publisher's Note: MDPI stays neutral with regard to jurisdictional claims in published maps and institutional affiliations.

The authors wish to make a change to the published paper [1]. There is an error in the Acknowledgments statement. The correct grant number for the Polish National Agency for Academic Exchange is No. PPI/APM/2019/1/00079/U/001. Meanwhile, the authors wish to move this content "The preparation of this paper was supported by the Polish National Agency for Academic Exchange under Grant No. PPI/APM/2019/1/00079/U/001" from the Acknowledgments Section to the Funding Section. The authors apologize for any inconvenience caused and state that the scientific conclusions are unaffected.

\section{Reference}

1. Lewicka, E.; Szlugaj, J.; Burkowicz, A.; Galos, K. Sources and Markets of Limestone Flour in Poland. Resources 2020, 9, 118. [CrossRef] 